\title{
PENGUJIAN SENSORIS NUGGET AYAM FORTIFIKASI DAUN KELOR
}

\author{
Sri Hastuti ${ }^{1}$, Sinar Suryawati ${ }^{2}$, Iffan Maflahah ${ }^{1}$ \\ ${ }^{1}$ Program Studi Teknologi Industri Pertanian \\ ${ }^{2}$ Program Studi Agroteknologi \\ Korespondensi : Fakultas Pertanian, Universitas Trunojoyo Madura \\ Jln. Raya Telang Kamal, Bangkalan \\ Email : arya_toet@yahoo.com
}

\begin{abstract}
Innovation chicken nuggets with fortification Moringa leaves can be expected as a source of protein as well as of other nutritional components needed by the body. Sensory testing nugget products have been set by the National Standardization Agency (BSN) is SNI No. 2346: 2011. The purpose of this study was to determine sensory and preference of chicken nuggets with fresh Moringa leaves and moringa leaf powder 2\% fortification. The results showed that the sensory testing of the appearance, smell, taste and texture nuggets still appropriate ISO standard that is above 7. While testing of the texture, taste, color and odor generating value from moderate like to like.
\end{abstract}

Keywords: nuggets, Moringa leaves, sensory

\section{PENDAHULUAN}

Dewasa ini masyarakat menyukai makanan yang serba cepat saji, salah satunya adalah nugget. Nugget terbuat dari gilingan daging dengan beberapa bahan penambah seperti tepung terigu, bumbu, telur dan lainlain yang digulir dalam tepung panir (Afrianto dan Evi, 1989). Nugget merupakan makanan ringan yang sekaligus dapat berfungsi sebagai lauk. Nugget sangat disukai anak-anak maupun orang dewasa karena ukurannya yang kecil dan rasanya yang mengandung selera.

Produk nugget dapat dibuat dari daging sapi, ayam, ikan dan lain-lain, tetapi yang populer di masyarakat adalah nugget ayam. Bahan baku daging untuk nugget, dapat menggunakan bagian daging dari karkas. Jenis daging ini bernilai ekonomis rendah (misalnya karena cacat, bukan karena telah rusak atau tidak segar) jika dijual dalam bentuk utuh.

Bahan pendukung lain yang digunakan pada pembuatan nugget antara lain es batu, $\mathrm{NaCl}$ (garam dapur), STPP (senyawa fosfat), maizena, bumbu, terigu, dan tepung roti. Selain sebagai pembangkit rasa, garam bersama senyawa fosfat akan membantu pembentukan gel protein ayam dengan baik sehingga nugget yang dihasilkan teksturnya kompak dan padat. Cara lain, dengan menggunakan es batu, CMC dan maizena sebagai pengikat. Es membuat suhu tetap rendah, dengan begitu terjadi pembentukan gel yang baik. Tepung terigu dan maizena digunakan sebagai adonan pelapis sebelum dilapisi dengan tepung roti (Suhartini dan Nur, 2005).

Salah satu kekurangan makanan cepat saji adalah kurangnya sayuran. Oleh karena itu dibutuhkan suatu inovasi makanan cepat saji dengan penambahan sayuran sehingga kebutuhan akan serat sayuran bisa dipenuhi. Beberapa sayuran yang telah ditambahkan dalam proses pembuatan nugget yaitu bayam, brokoli, wortel, dan lain-lain. Salah sayuran yang berpotensi ditambahkan dalam nugget adalah daun kelor (Moringa oleifera $L$ ).

Daun kelor (Moringa oleifera $L$ ) berbentuk bulat telur dengan ukuran kecilkecil bersusun majemuk dalam satu tangkai, dapat dibuat sayur atau obat. Bayi dan anakanak pada masa pertumbuhan dianjurkan Organisasi Kesehatan Dunia WHO mengkonsumsi daun kelor karena terdapat beberapa kelebihan komponen gizi dalam setiap gram yaitu daun kelor mengandung $7 \mathrm{x}$ vitamin $\mathrm{C}$ daripada jeruk, $4 \mathrm{x}$ kalsium daripada susu, $4 \mathrm{x}$ vitamin A daripada wortel, $2 \times$ protein daripada susu, dan $3 \times$ potasium 
daripada pisang (Kurniasih, 2015). Menurut Toripah et al (2014) bahwa daun kelor merupakan sumber antioksidan kategori sedang dengan nilai $\mathrm{IC}_{50}$ (kemampuan untuk menangkal radikal bebas 50\%) sebesar 111,7 ppm. Hasil penelitian Nugraha (2013) menyebutkan bahwa daun kelor dengan pelarut air mampu menghambat pertumbuhan E.Coli dengan konsentrasi $50 \%$. Wahyuni et al (2013) melaporkan bahwa daun kelor bisa digunakan untuk mengobati penyakit Hepatitis B. Hal ini memperlihatkan bahwa daun kelor sangat berpotensi sebagai sumber gizi dan pengobatan yang sangat baik untuk tubuh kita.

Inovasi nugget ayam dengan fortifikasi daun kelor diharapkan dapat sebagai sumber protein sekaligus sumber komponen gizi lain yang dibutuhkan tubuh. Pemunculan produk baru perlu dilakukan pengujian sensoris sehingga dapat diterima konsumen dengan baik. Pengujian sensoris melibatkan indera penglihatan, perasa dan pembau. Pengujian sensoris produk nugget telah diatur oleh Badan Standarisasi Nasional (BSN) yaitu SNI No 2346 : 2011.

\section{METODE PENELITIAN}

\section{Bahan}

Sampel yang digunakan pada penelitian yaitu daun kelor yang berasal disekitar kecamatan Kamal, Madura. Sedangkan bahan untuk pembuatan nugget adalah ayam, tepung terigu, bawang merah, bawang putih, merica, garam, es batu, susu full cream, dan tepung panir.

Alat

Peralatan yang digunakan adalah cabinet drying, panci, baskom, penggorengan dan pengukus.

\section{Prosedur Kerja}

\section{Pembuatan Serbuk Daun Kelor}

Daun kelor (Moringan oleifera) yang digunakan adalah daun muda yang dipetik dari dahan pohon yang kurang lebih dari tangkai daun pertama (di bawah pucuk) sampai tangkai daun ketujuh yang masih hijau. Daun dibersihkan dari kotoran yang menempel dengan air yang mengalir sampai benar-benar bersih. Kemudian daun dikeringkan dengan cara dikeringkan dalam cabinet drying pada suhu $40^{\circ} \mathrm{C}$ selama \pm 8 jam sampai benar-benar kering. Setelah kering daun kelor dihaluskan menjadi serbuk dengan menggunakan blender, dan kemudian di ayak 60 mesh.

\section{Pembuatan Nugget}

Tahapan pembuatan nugget adalah sebagai berikut :

- Haluskan daging dengan gilingan daging atau penumbuk atau blender dengan penambahan es batu dan garam

- Susu 1/2 sachet dicairkan dengan air, tepung terigu, daun kelor segar dan serbuk daun kelor $2 \%$

- Campur daging hasil gilingan dengan bumbu, lalu uleni hingga merata.

- Masukkan adonan ke dalam cetakan dan kukus selama 30 menit, lalu dinginkan

- Potong-potong adonan sesuai dengan selera

- Celupkan potongan adonan ke dalam telur, kemudian gulingkan ke tepung roti beberapa kali.

- Goreng potongan adonan sampai kering.

\section{Pengujian Sensoris Nugget}

Pengujian sensoris nugget berdasarkan SNI No 2346 : 2011 (Tabel 1). Nugget layak diperjualkan ke pasar dan dan mendapat sertifikasi jika nilai minimal 7 dengan jumlah panelis tidak terlatih sejumlah 30 orang.Sedangkan untuk pengujian kesukaan dilakukan dengan skala hedonik dengan skala 1 sampai 7 (Tabel 2). 
Tabel 1. Kuisioner Pengujian sensoris

\begin{tabular}{|c|c|c|c|c|c|}
\hline No & Spesifikasi & Nilai & \multicolumn{3}{|c|}{ Kode Sampel } \\
\hline 1 & Kenampakan & & 151 & 132 & 145 \\
\hline & $\begin{array}{ll}\text { - } & \text { Lapisan tepung roti kering, cemerlang } \\
\text { spesifik produk }\end{array}$ & 9 & & & \\
\hline & $\begin{array}{l}\text { Lapisan tepung roti kering, kurang } \\
\text { cemerlang spesifik produk }\end{array}$ & 7 & & & \\
\hline & $\begin{array}{l}\text { - Lapisan tepung roti agak basah, agak } \\
\text { kusam }\end{array}$ & 5 & & & \\
\hline & - $\quad$ Lapisan tepung roti basah, kusam & 3 & & & \\
\hline 2 & $\mathrm{Bau}$ & & & & \\
\hline & - $\quad$ Kuat spesifik produk & 9 & & & \\
\hline & - $\quad$ Kurang kuat spesifik produk & 7 & & & \\
\hline & - $\quad$ Apek & 5 & & & \\
\hline & - $\quad$ Masam dan tengik & 3 & & & \\
\hline 3 & Rasa & & & & \\
\hline & $\begin{array}{ll}- & \text { Kuat spesifik produk } \\
\end{array}$ & 9 & & & \\
\hline & - $\quad$ Kurang kuat spesifik produk & 7 & & & \\
\hline & - $\quad$ Agak masam & 5 & & & \\
\hline & - $\quad$ Masam & 3 & & & \\
\hline 4 & Tekstur & & & & \\
\hline & - $\quad$ Padat, kompak & 9 & & & \\
\hline & - $\quad$ Agak padat, agak kompak & 7 & & & \\
\hline & - $\quad$ Agak lembek & 5 & & & \\
\hline & - $\quad$ Lembek & 3 & & & \\
\hline
\end{tabular}

Keterangan: 151 : kontrol (tanpa penambahan daun kelor)

132 : penambahan daun kelor segar $2 \%$

145 : penambahan serbuk daun kelor $2 \%$

Tabel 2. Kuisioner Pengujian Hedonik

\begin{tabular}{|c|c|c|c|c|c|c|c|c|}
\hline \multirow[t]{2}{*}{ No } & \multirow[t]{2}{*}{ Parameter } & \multicolumn{7}{|c|}{ Nilai Hedonik } \\
\hline & & 7 & 6 & 5 & 4 & 3 & 2 & 1 \\
\hline 1 & Tekstur & & & & & & & \\
\hline & 151 & & & & & & & \\
\hline & 132 & & & & & & & \\
\hline & 145 & & & & & & & \\
\hline 2 & Rasa & & & & & & & \\
\hline & 151 & & & & & & & \\
\hline & 132 & & & & & & & \\
\hline & 145 & & & & & & & \\
\hline 3 & Warna & & & & & & & \\
\hline & 151 & & & & & & & \\
\hline & 132 & & & & & & & \\
\hline & 145 & & & & & & & \\
\hline 4 & $\mathrm{Bau}$ & & & & & & & \\
\hline & 151 & & & & & & & \\
\hline & 132 & & & & & & & \\
\hline & 145 & & & & & & & \\
\hline
\end{tabular}

Keterangan : $\quad 7=$ amat sangat suka

6 = sangat suka

$5=$ Suka

$4=$ agak suka

3 = tidak suka

2 = sangat tidak suka

$1=$ amat sangat tidak suka 


\section{HASIL DAN PEMBAHASAN}

\section{Pengujian Sensoris}

Hasil pengujian sensoris nugget ayam fortifikasi daun kelor menghasilkan nilai seperti terlihat pada Tabel 3 .

Tabel 3. Hasil uji sensoris nugget

\begin{tabular}{|c|l|c|c|c|}
\hline \multirow{2}{*}{ No } & \multirow{2}{*}{ Spesifikasi } & \multicolumn{3}{|c|}{ Kode Sampel } \\
\cline { 3 - 5 } & & 151 & 132 & 145 \\
\hline 1 & Kenampakan & 8,41 & 7,02 & 7,12 \\
\hline 2 & Bau & 8,29 & 7,71 & 7,24 \\
\hline 3 & Rasa & 7,9 & 7,47 & 7,01 \\
\hline 4 & Tekstur & 7,59 & 7,71 & 7,56 \\
\hline
\end{tabular}

Keterangan :

151 : kontrol (tanpa daun kelor)

132 : penambahan daun kelor segar $2 \%$

145 : penambahan daun kelor kering $2 \%$

\section{Kenampakan}

Tabel 3 memperlihatkan bahwa ketiga sampel nugget memiliki nilai diatas 7 . Nugget tanpa penambahan daun kelor (kontrol) memiliki nilai tertinggi yang mengindikasikan bahwa kenampakan nugget mempunyai lapisan tepung roti kering dan cemerlang spesifik produk, sedangkan nugget dengan penambahan daun kelor segar $2 \%$ (132) memiliki nilai terendah dengan lapisan tepung roti kering dan kurang cemerlang spesifik produk. Hal ini disebabkan selama proses penggorengan terjadi proses browning. Proses browning tersebut disebabkan adanya reaksi maillard. Reaksi Maillard adalah reaksi pencoklatan non enzimatis yang terjadi karena adanya reaksi antara gula pereduksi dengan gugus amin bebas dari asam amino atau protein. Reaksi ini dapat menyebabkan perubahan sifat-sifat kimia dan fisiologis protein sehingga mempengaruhi nilai gizi bahan pangan baik warna maupun tekturnya (Purnomo, 1995).

Selain itu,daun segar yang ditambahkan pada nugget akan memberikan warna yang sangat hijau. Warna hijau disebabkan karena kelor mengandung klorofil dengan konsentrasi yang tinggi yaitu $6890 \mathrm{mg} / \mathrm{kg}$ bahan kering. Kelor mengandung $4 \mathrm{x}$ lebih banyakdibandingkan dengan wheatgrass (Kurniasih, 2015).

Penggunaan serbuk daun kelor $2 \%$ (145) memiliki nilai kenampakan lebih tinggi daripada daun segar $2 \%$. Penggunaan serbuk kelor yang kering menyebabkan penurunan aktivitas air dalam adonan sehingga terjadi proses penurunan warna coklat. Purnomo (1995) mengungkapkan bahwa bahan pangan yang mengandung protein, gula, minyak, garam, selulosa dan air yang memiliki nilai $\mathrm{A}_{\mathrm{w}}$ rendah akan menyebabkan reaksi pencoklatan non enzimatis berlangsung lebih lambat. Selain itu, daun kelor kering mengalami penurunan kandungan klorofil sehingga warna hijau yang dihasilkan tidak terlalu tajam/tua.

\section{Bau}

Tabel 3 menunjukkan bahwa kontrol memiliki nilai tertinggi, sedangkan penambahan daun kelor baik dalam bentuk segar maupun serbuk menyebabkan bau nugget menjadi kurang kuat/spesifik walaupun secara umum semuanya masih memiliki nilai diatas 7. Hal ini disebabkan daun kelor mempunyai bau yang khas.

\section{Rasa}

Tabel 3 memperlihatkan bahwa ketiga sampel nugget memiliki nilai di atas 7 . Nugget tanpa penambahan daun kelor (kontrol) memiliki nilai tertinggi yang mengindikasikan bahwa rasa nugget kuat, sedangkan penggunaan daun kelor baik dalam bentuk segar maupun kering akan mengurasi rasa spesifik nugget.

\section{Tekstur}

Sifat tekstur bahan pangan ditimbulkan oleh elemen struktural bahan pangan yang dapat dirasa oleh perabaan, terkait dengan deformasi, disintegrasi dan aliran dari bahan pangan dibawah tekanan alat ataupun penekanan di mulut oleh kunyahan gigi (Purnomo, 1995). Tabel 3 memperlihatkan bahwa sampel dengan penambahan daun kelor segar (132) memiliki nilai tertinggi. Hal ini dikarenakan nugget dengan kode 132 menghasilkan tingkat keempukan yang tinggi, mudah dikunyah dan tidak keras.

Nugget tanpa penambahan daun kelor (kontrol) memiliki nilai sedang, hal ini disebabkan protein yang terkoagulasi 
menyebabkan tektur nugget menjadi agak keras sehingga agak sulit dikunyah. Sedangkan penambahan serbuk daun kelor $2 \%$ menyebabkan nugget yang dihasilkan mempunyai tekstur yang keras dikarenakan gelatinisasi tepung. Semakin banyak tepung yang ditambahkan maka semakin banyak air yang bereaksi dengan tepung membentuk gel. Berkurangnya aktivitas air dalam nugget tersebut akan menyebabkan tekstur menjadi keras.

\section{Pengujian Hedonik (Kesukaan)}

Hasil nilai rata-rata pengujian kesukaan panelis terhadap nugget yang difortifikasi dengan daun kelor terlihat pada Tabel 4.

Tabel 4. Nilai rata-rata uji kesukaan

\begin{tabular}{|c|c|c|c|c|}
\hline \multirow[t]{2}{*}{ Perlakuan } & \multicolumn{4}{|c|}{ Parameter } \\
\hline & Tekstur & Rasa & Warna & Bau \\
\hline Kontrol & 5,35 & 5,53 & 5,76 & 5,24 \\
\hline $\begin{array}{l}\text { Daun segar } \\
2 \%\end{array}$ & 4,35 & 4,53 & 4,59 & 4,35 \\
\hline $\begin{array}{l}\text { Daun } \\
\text { kering } 2 \%\end{array}$ & 4,24 & 4,24 & 4,41 & 4,65 \\
\hline $\begin{array}{l}\text { Ta } \\
\text { secara kes } \\
\text { disukai pane } \\
\text { sampai san } \\
\text { dengan pe } \\
\text { kering } 2 \% \mathrm{r} \\
\text { agak suka } \\
\text { segar } 2 \% \mathrm{p} \\
\text { rasa, warna } \\
\text { daripada se } \\
\text { nugget deng } \\
2 \% \text { lebih d } \\
\text { lebih tajam. }\end{array}$ & $\begin{array}{l}\text { el } 4 \quad n \\
\text { uruhan } \\
\text { s dengan } \\
\text { t suka (5 } \\
\text { mbahan } \\
\text { emiliki ni } \\
\text { ampai su } \\
\text { da nugge } \\
\text { yang lebi } \\
\text { uk kering } \\
\text { n penamb } \\
\text { ukai kare }\end{array}$ & $\begin{array}{l}\text { emper } \\
\text { kontrc } \\
\text { nilai 1 } \\
76 \text { ), s } \\
\text { daun } \\
\text { ai kes } \\
\text { ka. P } \\
\text { mens } \\
\text { h disu } \\
2 \% \text {, } \\
\text { ahan s } \\
\text { na bat }\end{array}$ & $\begin{array}{l}\text { atkan } \\
\text { yang } \\
\text { lai suk } \\
\text { angkan } \\
\text { egar } \\
\text { aan mı } \\
\text { ambaha } \\
\text { asilkan } \\
\text { i oleh } \\
\text { cuali b } \\
\text { buk dau } \\
\text { ang dil }\end{array}$ & $\begin{array}{l}\text { bahwa } \\
\text { paling } \\
(5,24) \\
\text { nugget } \\
\text { laupun } \\
\text { ai dari } \\
\text { daun } \\
\text { ekstur, } \\
\text { banelis } \\
\text { u. Bau } \\
\text { kelor } \\
\text { ailkan }\end{array}$ \\
\hline
\end{tabular}

\section{KESIMPULAN}

Pengujian sensoris terhadap kenampakan, bau, rasa dan tektur nugget fortifikasi daun kelor sebesar $2 \%$ masih sesuai standar SNI yaitu diatas 7. Sedangkan pengujian kesukaan panelis pada tekstur, rasa, warna dan bau menghasilkan nilai dari agak suka sampai suka.

\section{DAFTAR PUSTAKA}

Afrianto,E. dan Evi Liviawaty. 1989. Pengawetan dan Pengolahan Ikan. Yogyakarta: Penerbit Kanisius.

Kurniasih. 2015. Khasiat dan Manfaat Daun Kelor untuk Penyembuhan berbagai Penyakit. Yogya : Pustaka Baru Press.

Nugroho, A. 2013. Bioaktifitas ekstrak daun kelor (Moringa oleifera) terhadap Eschericia Coli penyebab kolibasilosis pada babi. Thesis. Denpasar : Universitas Udayana.

Purnomo, H. 1995. Aktivita Air dan Peranannya dalam Pengawetan Pngan. Jakarta : Penerbit Universitas Indonesia (UI Press)

Suhartini,S dan Nur Hidayat. 2005. Olahan Ikan Segar. Surabaya : Trubus Agrisarana.

Toripah,S.S, Jemmy A, dan Frenky W. 2014. Aktivitas antioksidan dan kandungan fenolik ekstrak daun kelor (Moringa oleifera Lam). Jurnal PHARMACON volume 3 No 4: 37-43

Wahyuni,S, Muh Arif A, Miftahul,C.U.S, Sinta, W.N.S, Tri M, dan Rahajeng P. 2013. Uji manfaat daun kelor (Moringa oleifera) untuk mengobati Hepatitis B. Jurnal KesMaDasKa volume 4 No 2 : 100-103. 